NBER WORKING PAPER SERIES

\author{
REAL EXCHANGE RATE LEVELS, \\ PRODUCTIVITY AND DEMAND SHOCKS: \\ EVIDENCE FROM A PANEL OF \\ 14 COUNTRIES
}

Menzie Chinn

Louis Johnston

NBER Working Paper 5709

\author{
NATIONAL BUREAU OF ECONOMIC RESEARCH \\ 1050 Massachusetts Avenue \\ Cambridge, MA 02138 \\ August 1996
}

We thank Andy Levin for invaluable discussions of econometric issues. Helpful comments were received from Bob Cumby, Richard Lyons, Jaewoo Lee, participants at the NBER conference on the Determination of Real Exchange Rates, the Castor Workshop at the University of Washington, the IMF Research Department and the Federal Reserve Bank of Kansas City Research Division. This paper was written while the first author was a visiting scholar at the IMF, and has benefitted from financial support of faculty research funds from UC Santa Cruz (Chinn) and from Gustavus Adolphus College (Johnston). All remaining errors remain the sole responsibility of the authors. This paper is part of NBER's research program in International Finance and Macroeconomics and NBER's project on International Capital Flows. It was presented at the NBER's 'Universities Research Conference on the Determination of Exchange Rates. We are grateful to The Center for International Political Economy for the support of this project. Any opinions expressed are those of the authors and not those of the National Bureau of Economic Research.

(C) 1996 by Menzie Chinn and Louis Johnston. All rights reserved. Short sections of text, not to exceed two paragraphs, may be quoted without explicit permission provided that full credit, including (C) notice, is given to the source. 


\title{
REAL EXCHANGE RATE LEVELS, PRODUCTIVITY AND DEMAND SHOCKS: EVIDENCE FROM A PANEL OF 14 COUNTRIES
}

\begin{abstract}
This paper investigates the determinants of the real exchange rate using a panel of disaggregated data for the OECD countries. It also marries two literatures -- one which uses panel data to measure relationships between changes in exchange rates to changes in the determinants, and the other which uses cointegration techniques to measure the long-run relationship between the level of the exchange rate and the level of the determining factors. The previous panel studies cannot account for deviations from long-run trend levels, while the extant literature using time series cointegration techniques 'can only intermittently detect and measure posited relationships. Estimating the relationships in levels is an interesting enterprise because it allows one, in principle, to calculate trend real exchange rates.

After surveying the previous literature, a dynamic model of the real exchange rate is used to motivate the empirical exercise. In examining this problem, we will exploit recent developments in the econometric analysis of nonstationary variables in panel data. The results indicate that under certain assumptions it is easier to detect cointegration in panel data than in the available time series; moreover, the estimates of reversion to trend are also estimated with greater precision. The most empirically successful models include productivity measures, government spending ratios, and either the terms of trade, or the real price of oil. Using this latter model, we find that the implied equilibrium exchange rates indicate less overvaluation of the dollar than that implied by a naive version of purchasing power parity.

Menzie Chinn

Department of Economics

Social Sciences I

University of California

Santa Cruz, CA 95064

and NBER

chinn@cats.ucsc.edu

Louis Johnston

Department of Economics

Gustavus Adolphus College

St. Peter, MN 56082
\end{abstract}




\section{Introduction}

The real exchange rate is a key relative price in international finance. Thus it is not surprising that so much attention has been lavished upon finding the determinants of this variable in both the short and long run. It is surprising that the empirical success in explaining movements in the real exchange rate has been so limited.

This paper investigates the determinants of the real exchange rate using a panel of disaggregated data for the OECD countries. It does this by marrying two literatures -- one using panel data to measure relationships between changes in exchange rates to changes in the determinants, and the other using cointegration techniques to measure the long-run relationship between the level of the exchange rate and the level of the determining factors.

This enterprise is a useful one because previous cross-section analyses cannot speak to the equilibrium level of the exchange rate. On the other hand, the extant literature using timeseries techniques is limited by the fact that it is difficult to extract reasonable estimates of the long-run cointegrating vectors from the short spans of data available. In examining this problem, we will exploit recent developments in the econometric analysis of nonstationary variables in panel data. ${ }^{1}$

The paper is organized in the following manner. Section 2 reviews the previous literature. Section 3 describes the model used to motivate the analysis. Section 4 describes the time series techniques implemented and results. Section 5 discusses the panel regression

${ }^{1}$ Canzoneri, Cumby and Diba (1996) use similar panel regression techniques to identify long run relationships between relative productivity levels and relative prices, as well as purchasing power parity for traded goods. 
techniques and estimation results. Section 6 compares the equilibrium exchange rates implied by the productivity based model to those derived from a simple purchasing power parity criterion. Section 7 concludes.

\section{Previous Literature}

Previous analyses of productivity-based models of the real exchange rate can be broken up into three, somewhat distinct groups. The first group adopts the Balassa (1964) and Samuelson (1964) approach straightforwardly, so that the relative price of nontradables is determined exclusively by supply side factors, such as productivity. The second group introduces some type of rigidity, such as adjustment costs to reallocating factors of production between sectors, so that demand factors also determine the real exchange rate. Both of these two groups are static in nature; there are no intertemporal considerations. The third approach adopts an explicitly intertemporal approach, and may or may not include a specific-factors assumption. Each of these approaches are briefly described below.

\subsection{Static Productivity-Based Models}

Suppose the price level can be expressed as a geometric average of the tradable and nontradable goods price indices, where all variables are expressed in logs:

$$
p_{t}=\Omega p_{t}^{N}+(1-\Omega) p_{t}^{T}
$$

Then defining the real exchange rate as the aggregate price index deflated exchange rate yields the following expression, assuming purchasing power parity (PPP) holds for tradable goods. 


$$
\begin{aligned}
q_{t} & \equiv\left(s_{t}+p_{t}^{*}-p_{t}\right) \\
& =\Omega\left(s_{t}+p_{t}^{N *}-p_{t}^{N}\right)
\end{aligned}
$$

where $s$ is the nominal exchange rate, and an asterisk denotes the foreign country. The real exchange rate is a function of the relative price of nontradables. This point has been incorporated in various models of the nominal exchange rate where the long-run real exchange rate is allowed to vary over time. ${ }^{2}$

The Balassa-Samuelson model is well known, so that an explicit derivation will not be presented (see Asea and Corden (1994)). Assuming perfect international integration of goods and capital markets, the price of tradables and the interest rate are set. The former then determines the wage rate, which given intersectoral factor mobility means that relative prices are set exclusively by the level of productivity in the two sectors. Since both factors are free to move between sectors costlessly, only supply side factors matter. Hence:

$$
q_{t}=-\Omega\left[\left(\frac{\theta^{N}}{\theta^{T}}\right) a_{t}^{T}-a_{t}^{N}\right]+\Omega\left[\left(\frac{\theta^{N *}}{\theta^{T *}}\right) a_{t}^{T *}-a_{t}^{N *}\right]
$$

where $\theta$ is the labor coefficient in a Cobb-Douglas production function and $a$ is log-total factor productivity.

Typically, the regressions are implemented in the following form:

$$
\Delta q_{t}=\beta_{0}+\beta_{1} \Delta\left(a_{t}^{T}-a_{t}^{N}\right)+\beta_{2} \Delta\left(a_{t}^{T *}-a_{t}^{N *}\right)+\text { other regressors }+u_{t}
$$

\footnotetext{
${ }^{2}$ Wolff (1987) and Chinn and Meese (1995). See also the literature survey in Isard and Symansky (1995).
} 
Table 1 summarizes the empirical estimates for the role of productivity in such regressions. Hsieh (1982) estimates the determinants of the multilateral exchange rates for Germany and Japan over the 1954-76 period, using labor productivity. He finds that the coefficient $B_{1}\left(B_{2}\right)$ is $-0.362(.516)$ for Germany, and $-0.538(0.538)$ for Japan (although he allows for deviations from PPP for tradable goods). This coefficient is interpretable as the share of nontradables in the aggregate price index.

Marston (1990) adopts a similar approach, examining five bilateral exchange rates over the $1973-86$ period. He obtains estimates considerably higher, ranging from -0.714 for the Franc/Deutschemark rate, to -1.244 for the Dollar/Deutschemark $\left(B_{1}\right.$ is constrained to equal $B_{2}$ ). Micossi and Milesi-Ferretti (1994) estimate a similar relationship for multilateral real exchange rates over the $1970-1990$ period. They find that the estimates for $B_{1}\left(B_{2}\right)$ range from $-0.10(-0.05)$ to $-0.76(1.10)$. All the coefficients are correctly-signed except for the anomalous case of Denmark.

These studies indicate that there is a statistically significant relationship between labor productivity and the real exchange rate. However, the results differ by specification, by sample and data type. More importantly, it is not clear how good a proxy labor productivity is for total factor productivity (TFP).

It is important to observe that estimation in first difference is consistent with the view that there is no meaningful concept of reversion to the productivity-determined equilibrium exchange rate. Alternatively, there is no distinction between short and long run effects. To illustrate that the adoption of this econometric specification is not without consequence, an analogy to the consumption function may prove useful. A regression of changes in consumption on changes in income will produce an estimated equation that may pass the 
usual diagnostic tests. However, such a regression implicitly rules out a permanent income hypothesis view of consumption since there is no long-run tie between the level of consumption and the level of income (both integrated regressors) in such a regression.

Similarly, it is possible that each of the series in this study individually contains a unit root, but together form a linear combination that is stationary, i.e., the two series are cointegrated. Strauss (1995) addresses this issue using the Johansen (1988) and Johansen and Juselius (1990) maximum likelihood procedure. He tests for a cointegrating relationship between the bilateral real exchange rate (versus Deutschemark) and relative productivity variables, where total factor productivity (TFP) is used instead of labor productivity. While TFP is the appropriate variable, it also limits the span of the data series for five of 14 countries to 21 years. Using the conventional asymptotic critical values from OsterwaldLenum (1992), he finds that eight cases are cointegrated at the $10 \%$ marginal significance level. However, if one adjusts for small sample effects (Cheung and Lai, 1993a), then the number of cases of cointegration drops to a mere two: UK and possibly France. Under no conditions does Japan exhibit cointegration, which is odd, given the apparent fit of the Japanese case. This oddity suggests that an important variable is (or variables are) omitted. ${ }^{3}$

${ }^{3}$ Strauss does not report the parameter estimates obtained from the Johansen procedure, so it is difficult to evaluate the conformity of the results with any particular theoretical model. He does report likelihood ratio tests for restrictions on the cointegrating vector. In general the cointegrating vector linking productivity and relative prices, and the cointegrating vector linking relative prices and the real exchange rate, reject the implied restrictions. However, two points are relevant. First, the validity of such tests are conditional upon the existence of a cointegrating vector, which is in doubt. Second, these tests may also be sensitive to finite sample size effects (see Gagnon, Edison and Melick, 1994). 


\subsection{Static Productivity-Based Models with Rigidities}

DeGregorio, Giovannini and Wolf (1994) use the Balassa-Samuelson model to motivate why nontradable inflation has been more rapid than that for tradables. They point out that demand side factors will affect the real exchange rate only if the assumption of perfect competition, PPP for traded goods, or perfect capital mobility are relaxed. DeGregorio and Wolf (1994) pursue this last line of inquiry. They present a model that nests the productivity model of Balassa-Samuelson, so that supply and demand shocks have an effect on the real exchange rate.

DeGregorio and Wolf estimate a number of first-differenced specifications which include terms of trade effects, government spending shocks, and changes in preferences regarding the consumption of nontradables, proxied by the income level. They also utilize total factor productivity as their productivity measure, and obtain panel regression estimates of the productivity coefficient ranging from -0.10 to -0.26 . Their results also indicate that the coefficient on the preferences variable (where preferences are proxied by income per capita) are not robust to the inclusion of terms-of-trade shocks. However, this outcome may be partly a consequence of the choice of estimating in first differences, since the low-frequency effect of changing tastes is unlikely to be manifested in year to year changes in income.

\subsection{Dynamic Models}

Froot and Rogoff (1991) present an intertemporal model incorporating nontradables. Consumption smoothing can only by mediated by exchange in tradables; since consumption of nontradables must match production, government demand shocks that fall on tradables and nontradables in different proportions than those of the private sector will have an affect on 
exchange rates. Assuming endogenous output and fixed sectoral capital, the real exchange rate is then a function of productivity differentials, although the intertemporal character of the model means that the exchange rate only responds to unanticipated productivity shocks.

Rogoff (1992) extends the intertemporal model, allowing for fixed factors, in order to account for the stylized fact that there is high persistence in the real exchange rate, without relying on unit root productivity shocks. The open capital account version of this model implies that unanticipated productivity shocks cause highly persistent movements in the real rate.

Rogoff estimates the response of the exchange rate to a manufacturing labor productivity shock of -0.6 to -0.7 using a first differences specification (no data on nontraded productivity is available at the quarterly frequency analyzed in this paper). If the driving variables actually follow unit root processes then a cointegration framework is the natural one to adopt. Chinn (1995) found evidence of cointegration between the real exchange rate, manufacturing productivity, and government spending, for the Canadian Dollar, the Deutschemark, Yen and Pound. However only for the $\$ / Y$ rate does there appear to be plausibly estimated cointegrating vectors. For this rate, Chinn (1996) estimates the long run response at -0.815 , with standard errors of 0.13 . This implies that the $95 \%$ confidence bounds range from -0.555 to -1.075 .

Estimation of the cointegrating relationship using error correction models also allows one to assess the strength of the relationship -- that is, how quickly are deviations from the implied equilibrium eliminated. Chinn finds the rate of reversion of the $\$ / \mathbb{Y}$ rates to be very rapid. A deviation half life is about 1.5 years. However, all these inferences are cast in doubt by the lack of adequate nontradables sector productivity data. 
In summing up the literature, one can conclude that there is substantial evidence for a productivity based model of the real exchange rate. However, due to statistical and datarelated limitations, one cannot conclude that there is a robust relationship between the level of the productivity differential and the level of the real exchange rate.

\section{THEORETICAL MODEL}

The empirical portion of this paper is motivated by a variant of Rogoff's (1992) model, alluded to above. The model specifies production and consumption in the context of intertemporal optimization. The supply side is given by Cobb-Douglas production functions:

$$
\begin{aligned}
& Y_{t}^{T}=A_{t}^{T}\left(L_{t}^{T}\right)^{\theta T}\left(K_{t}^{T}\right)^{1-\theta T} \\
& Y_{t}^{N}=A_{t}^{N}\left(L_{t}^{N}\right)^{\theta N}\left(K_{t}^{N}\right)^{1-\theta N}
\end{aligned}
$$

where $\mathrm{Y}^{\mathrm{T}}$ and $\mathrm{Y}^{\mathrm{N}}$ are output of the traded and nontraded goods. $\mathrm{L}, \mathrm{K}$ and $\mathrm{A}$ represent labor, capital and stochastic productivity shocks. The demand side is given by a representative agent that maximizes a time-separable utility function:

$$
V_{t}=E_{t} \sum_{s=0}^{\infty} \beta^{s-t}\left(\frac{\left(\left(C_{s}^{N}\right)^{\alpha}\left(C_{s}^{T}\right)^{1-\alpha}\right)^{1-\gamma}}{1-\gamma}\right)
$$

where is $B$ is the subjective discount rate, $C^{\mathrm{T}}$ and $C^{\mathbb{N}}$ are the consumption of traded and nontraded goods respectively, and $\gamma$ is the inverse of the elasticity of intertemporal substitution.

In this model, an intertemporal budget constraint holds; however, the only way to save and borrow is through trade in tradables. Moreover, private and government consumption in 
each sector must equal output period by period; hence the relative price of nontraded goods each period must depend upon the relative domestic consumption of the two goods:

$$
\tilde{P}_{\mathrm{t}}=\frac{\alpha C_{t}^{T}}{(1-\alpha) C_{t}^{N}}
$$

where $P_{r}$ is the relative price of nontraded goods in terms of traded.

The first order conditions imply that agents smooth expected marginal utility over time; this is approximated by the following expression (in logs):

$$
E_{t}\left(c_{t+1}^{T}-c_{t}^{T}\right) \approx \frac{\alpha(1-\gamma)}{\gamma+\alpha(1-\gamma)} E_{t}\left(c_{t+1}^{N}-c_{t}^{N}\right)
$$

assuming that the productivity shocks are homoscedastic, and there is no consumption tilting.

Combining equations (8) and (9), Rogoff shows that:

$$
\tilde{p}_{t+1}-\tilde{p}_{t}=\left(c_{t+1}^{T}-c_{t+1}^{N}\right)-\left(c_{t}^{T}-c_{t}^{N}\right)
$$

To obtain an empirically implementable model, assume that government spending (assumed to fall solely on nontradables) follows a random walk, and further that productivity shocks are lognormally distributed:

$$
\begin{aligned}
& a_{t+1}^{N}=a_{t}^{N}+e_{t}^{N} \\
& a_{t+1}^{T}=a_{t}^{T}+e_{t}^{T}
\end{aligned}
$$

Then one obtains the following expression for the first difference of the relative price of nontradables: 


$$
\tilde{p}_{z+1}-\tilde{p}_{z}=\left(a_{t+1}^{T}-a_{t}^{T}\right)-\zeta_{N}\left(a_{t+1}^{N}-a_{t}^{N}\right)+\left(\zeta_{N}-1\right)\left(g_{t+1}-g_{t}\right)
$$

where $\zeta_{\mathrm{N}}$ is the ratio of nontraded goods output to private nontraded goods consumption. ${ }^{4}$

In order to re-write equation (11) in terms of a long-run cointegrating relationship, recursively substitute backwards to obtain:

$$
\tilde{p}_{t+1}=a_{t+1}^{T}-\zeta_{N} a_{t+1}^{N}+\left(\zeta_{N}-1\right) g_{t+1}+p_{0}
$$

where $p_{0}$ is some initial condition.

Thus far, the real exchange rate in this model is a relative price between tradables and non-tradables in a single country. In order to convert this model into one that describes the more familiar relative price of two currencies, assume that there is an identical foreign country. Subtracting one from the other yields:

$$
\begin{aligned}
\tilde{p}_{t+1}-\tilde{p}_{t+1}^{*} & \equiv\left(p_{t+1}^{N}-p_{t+1}^{T}\right)-\left(s_{t}+p_{t+1}^{N *}-s_{t}-p_{t+1}^{T *}\right) \\
& =\hat{a}_{t+1}^{T}-\zeta_{N} \hat{a}_{t+1}^{N}+\left(\zeta_{N}-1\right) \hat{g}_{t+1}+\hat{p}_{0}
\end{aligned}
$$

where the circumflexes $\left({ }^{n \wedge}\right)$ denote relative differences. Assuming purchasing power parity (PPP) for tradables implies:

$$
\left(s_{t+1}+p_{t+1}^{N *}-p_{t+1}^{N}\right)=\hat{a}_{t+1}^{T}-\zeta_{N} \hat{a}_{t+1}^{N}+\left(\zeta_{N}-1\right) \hat{g}_{t+1}+\hat{p}_{0}
$$

Then using the conventional (CPI deflated) definition of the real exchange rate described in (2), one obtains:

${ }^{4}$ Note that this expression differs from Rogoff's (1992) equation (21), in that here $\rho$, the autoregressive coefficient on tradables productivity, is set to 1 . If $\rho<1$, then the implied time series process for all variables would be trend stationary. We view this as an empirical issue, to be addressed in Section 4. 


$$
q_{t+1}=-\Omega\left[\hat{a}_{t+1}^{T}-\zeta_{N} \hat{t}_{t+1}^{N}+\left(\zeta_{N}-1\right) \hat{g}_{t+1}+\hat{p}_{0}\right]
$$

This equation provides us with a theoretically implied cointegrating relationship between the real exchange rate, relative productivity levels in the tradables and nontradables sectors, and government spending (expressed as a proportion of GDP).

In the estimation portion of the paper, we are not dogmatic about the specification; the importance of other candidate regressors is also evaluated. For instance, on the demand side, terms of trade shocks and per capita income are also included. Terms of trade shocks can affect wealth, as well as intertemporal consumption patterns, thereby affecting the real exchange rate (see Roldos, 1990). Income per capita is included as a proxy for nonhomotheticity of consumption preferences; that is, as income or wealth rises, consumer preferences shifts toward nontraded goods, such as services. ${ }^{5}$ On the supply side, the equation is augmented with the real price of oil, to account for possible shifts in the production function.

\section{TIME SERIES APPROACHES}

\subsection{Time Series Econometric Methodologies}

The current standard in testing for cointegration in time series is the full-system maximum likelihood estimation technique of Johansen (1988). Let $x_{t}$ be a $m \times 1$ vector of I(1) variables. Then one can estimate the VAR(p):

5 Technically, this non-homotheticity is inconsistent with the intertemporal model. 


$$
\Delta x_{t}=\mu+\Gamma_{1} \Delta x_{t-1}+\Gamma_{2} \Delta x_{t-2}+\ldots \Gamma_{p-1} \Delta x_{t-p+1}+\amalg x_{t-p}+u_{t}
$$

where $\Gamma_{1}, \Gamma_{2}, \ldots \Gamma_{\mathrm{p}-1}, \mathrm{I}$ are $\mathrm{m} \times \mathrm{m}$ matrices of unknown parameters, and $\mathrm{u}$ is distributed $\mathrm{N}(0, \Sigma)$. The matrix II is estimated by the Johansen maximum likelihood procedure subject to the hypothesis that II has reduced rank (i.e., $\mathrm{r}<\mathrm{m}$ ). This hypothesis is written:

$$
H(r): \text { II }=\alpha \beta^{\prime} ; \operatorname{Rank}(\mathrm{II})=r
$$

where $\alpha$ and $B$ are $m \times r$ matrices. If $r<m$ then under certain conditions the $B^{\prime} x_{1}$ is stationary (i.e., the $x$ are cointegrated).

There are two tests proposed by Johansen, and described in greater detail in Johansen and Juselius (1990). Typically, the asymptotic critical values are drawn from OsterwaldLenum (1992). Cheung and Lai (1993a) have shown that finite sample critical values may be more appropriate given the relatively small samples which are generally under study. ${ }^{6}$

Since results obtained using the Johansen technique appear to be sensitive to the selection of lag length, especially in small samples, we also consider estimates derived by alternative means. Phillips and Loretan (1991) argue on the basis of simulation evidence that single-equation error correction models can be a useful method to estimating long run relationships. In particular, they assert that estimation of an error correction model using nonlinear least squares regression, including leads of the first difference of the right-hand side variables provides asymptotically superior estimates. The Phillips-Loretan (hereafter "PL$N_{L S}$ ) specification of equation (15) is:

6 The finite sample critical values are obtained by adjusting the asymptotic critical values for the loss of degrees of freedom due to the estimation of the parameters describing the short term dynamics. The adjustment factor is given by $(\mathrm{N}-(\mathrm{p} \times \mathrm{m})) / \mathrm{N}>1$. We thank Yin-Wong Cheung for graciously allowing us to use his computer programs. 


$$
\begin{aligned}
\Delta q_{t} & =\alpha_{0}+\alpha_{1}\left(q_{t-1}-B_{1} \hat{a}_{t-1}^{T}-B_{2} \hat{a}_{t-1}^{N}-B_{3} \hat{g}_{t-1}\right) \\
& +\xi_{1} \Delta \hat{a}_{t+1}^{T}+\xi_{2} \Delta \hat{a}_{t+1}^{N}+\xi_{3} \hat{g}_{t+1} \\
& + \text { lagged difference terms }+u_{t}
\end{aligned}
$$

This specification includes one lead of the differenced independent variables, which serves to orthogonalize the error term in the presence of feedback from the left-hand-side variable to the right-hand-side variables.

\subsection{Data}

The data are all annual, covering the 1970-91 period. Bilateral real exchange rates are calculated using nominal exchange rates and consumer price indices (CPIs) taken from the IMF's International Financial Statistics. The terms of trade and the price of oil are also from IFS. The former is calculated as the log-ratio of export prices to import prices (in US dollars). The latter is the log price in US dollars, deflated by the US CPI.

The aggregate total factor productivity (TFP) data were constructed from the OECD's International Sectoral Database (ISDB), which contains TFP disaggregated by sector. The tradable and nontradable categorization is the same as that used by DeGregorio, Giovannini and Wolf (1994). Tradable sectors include agriculture, mining, manufacturing, and transportation, while the nontradable sectors include all other services.

The government spending variable is the ratio of real government consumption, divided by real GDP. These data come from the OECD's National Accounts. The "preferences" variable is GDP per capita, where GDP is measured in Summers and Heston "International" dollars (the chain-weighted variable, RGDPCH). This variable is meant to proxy for the 
rising preference for services as income rises. The data were drawn from the Penn World Tables, Mark V.

\subsection{Time Series Results}

Preliminary analysis of the data indicated that the relevant variables could not generally reject the null hypothesis of difference stationarity at the 5\% MSL, using an ADF test (1 lag, w/trend). There were two exceptions: tradable productivity differentials for Great Britain and Canada. For the German nontradable productivity differential, it was not possible to obtain an adequate specification, so it is not clear what the time series properties of this variable are.

We attempted to apply the Johansen maximum likelihood technique to the time series data. As we anticipated, so many parameters had to be estimated that no test statistics exceeded the adjusted (finite sample) critical values. Hence we could not rely upon the Johansen results to inform us regarding the cointegration properties of the data.

In Table 2, single-equation time-series estimates are reported for the reversion parameter, and the tradables productivity coefficient from a basic regression of the real exchange rate on productivity differentials and government spending ratios, ${ }^{7}$ The first two columns report the estimates from error correction specifications, estimated using nonlinear least squares (NLS), without and with a time trend. The third and fourth columns report the results for the Phillips-Loretan NLS (PL-NLS) analogues. These estimates are also reported in Figures 1 and 2.

7 We also tried including terms of trade and oil price variables. The coefficients on these variables failed to exhibit statistical significance in most cases. 
In Panel A, the rate of reversion parameter estimates are reported. A statistically significant negative coefficient indicates that the real exchange rate reverts to a conditional mean defined by the cointegrating vector. Panel B reports the coefficient on tradable productivity. A statistically negative coefficient estimate implies that more rapid productivity growth in the tradable sector is associated with an appreciation of the real exchange rate.

The estimates in Panel A indicate that there is substantial, and statistically significant, ${ }^{8}$ evidence of reversion to conditional mean, regardless of whether a time trend is included or not. Moreover, the results are not very sensitive to inclusion of a lead of the dependent variable, although there are definitely exceptions to both assertions.

More surprising is the fact that the coefficient on tradable productivity, a key variable in all these productivity-based model, is almost always of the wrong sign, and significantly so (in both economic and statistical terms). These results are very sensitive to the inclusion of a time trend; the Japanese coefficient for instance switches sign from roughly -3 to +3 .

The lack of robust results here mirrors those obtained by other researchers. In Figures 3 and 4 , the estimates for the nontradable productivity coefficients and the foreign government spending coefficients are illustrated. (The US government spending coefficients are not shown since they are all significant, and in the correct direction.) Once again, the PLNLS estimates are widely dispersed. More disconcerting, the foreign government spending coefficient is, more often than not, of the wrong sign.

\footnotetext{
${ }^{8}$ The significance levels are based on asymptotic standard errors, which are appropriate if the error terms are white noise (Banerjee, et al. 1993). In fact, all regressions equations fail to reject a F-test for serial correlation of order 2 and 4, except for Norway.
} 


\section{PANEL REGRESSION APPROACHES}

\subsection{Panel Regression Methodology}

We consider a variant of equation (15) where the data are indexed by country:

$$
q_{i, s+1}=-\Omega\left[\hat{a}_{i, t+1}^{T}-\zeta_{N} \hat{a}_{i, t+1}^{N}+\left(\zeta_{N}-1\right) \hat{g}_{i, t+1}+\hat{p}_{i, 0}\right]
$$

If the series were individually taken to be stationary series, then conventional panel regression techniques could be applied. If one wished to assume that the errors were correlated across exchange rates, and further that the right-hand side variables were exogenous with respect to the regressand, then seemingly unrelated regression estimation (SURE) would be appropriate.

The application of conventional panel regression techniques is complicated by the possible nonstationarity of the series involved. It is no surprise that almost no variable rejects the unit root null, using an ADF test (w/trend, $1 \mathrm{lag}$ ). As a consequence, one must proceed with caution. Since we are concerned with long-run relationships in levels, we refrain from first differencing the data. Instead, we proceed in the following manner: we estimate the cointegrating relationships, and then test whether the residuals from these cointegrating vectors are stationary according to a unit root test.

Since we are estimating the cointegrating relationship with individual-specific effects only in the constant, and homogeneity imposed across the individual slope coefficients, the panel estimator converges to a Normal, although quite slowly. ${ }^{9}$ We regress the differenced residual from the cointegrating vectors implied by the regressions in Table 3 on the lagged residual, and country dummies.

9 Assuming further that the right hand side variables are weakly exogenous. 


$$
\Delta E C T_{i, t}=+\alpha E C T_{i, s-1}+\text { currency dummies }+u_{i, t}
$$

The t-statistic on the $\alpha$ coefficient is then compared against the tabulated critical values in Table 5 of Levin and Lin (1992). If the test statistic is statistically significant, then the null of no cointegration can be rejected.

We applied this test to a composite variable where the following theoretical priors were imposed: the share of nontradables in the CPI is set to $.5, \zeta_{\mathrm{N}}$ is set to .4 , the coefficient on government spending is set to 5 , and that on oil is set to 0.2 . The resulting t-statistic on the error correction term is -5.283 , which exceeds the Levin-Lin 1\% MSL critical value. ${ }^{10}$ Hence, there is evidence that real exchange rates are cointegrated with productivity differentials and government spending even when just using imposed coefficients.

\subsection{Estimating the Cointegrating Relationships}

Estimation in levels, even with cointegrated variables, typically produces non-Normal distribution for the estimators (unless one is willing to assume $\mathrm{N}$ converges to infinity). We proceed by estimating the relationship in a nonlinear error correction specification, so that the distribution is asymptotically Normal. Consider (19) rewritten in nonlinear error correction form: ${ }^{11}$

${ }^{10}$ Note that the Levin and Lin procedure assumes independence of errors across individuals (here currencies). O'Connell (1996) has shown that allowing for cross-correlation increases the nominal size of such tests.

${ }^{11}$ In principle lagged first difference terms should also enter in, but these coefficients were seldom statistically significant in the single-currency regressions, and so were not included. Inclusion of the first difference lags of the real exchange rate, and government spending variables does not change the qualitative results, but does reduce the statistical significance of the coefficients besides that on traded sector productivity. 


$$
\Delta q_{i, r}=\alpha_{i, 0}+\alpha_{1}\left(q_{i, r-1}-B_{1} \hat{a}_{i, r-1}^{T}-B_{2} \hat{a}_{i, r-1}^{N}-B_{3} \hat{g}_{i, r-1}\right)+u_{i, r}
$$

where the slope coefficient $\alpha_{1}$ is restricted to be the same across all currencies.

Using SUR is more appropriate than using a fixed-effects panel regression since the latter assumes that the contemporaneous shocks are random. The SUR estimator, on the other hand, explicitly takes into account the cross-currency correlation.

\subsection{Panel Regression Results}

An error correction specification of (19) was estimated using SUR, allowing for currency-specific constants. The results are reported in Table 3. The estimated coefficient of reversion in the most basic formulation (Column 1) is statistically significant, as is the coefficient on tradables productivity. ${ }^{12}$ The estimated rate of reversion is about 0.17 , implying that the half-life of a deviation from trend is about five years. This is somewhat slower than the four to five years purchasing power parity deviation half-life reported by Edison (1987), Frankel and Rose (1996) and Wei and Parsley (1995), for instance.

The estimates for the nontradable productivity and US government spending coefficients are of correct sign, although only the latter is of statistical significance. The negative estimate for foreign government spending, manifested in the individual time series regressions, shows up again. If the government spending coefficients on the US and foreign country are

${ }^{12}$ These regression results are qualitatively unchanged if short run dynamics, including the lagged differences of the real exchange rate and government spending ratios, are added. However, the level of significance for the tradable productivity coefficient drops to 0.13 ; moreover the implied cointegrating vector then only includes productivity and the real exchange rate. This result is likely due to the fewer degrees of freedom, once additional lag coefficients must be estimated. 
constrained to be of equal and opposite magnitude, then the estimates of reversion and on tradable productivity are basically unchanged, although the parameter estimates on the government spending variables become insignificant.

If the regression is augmented with a terms of trade variable, then the coefficient on tradable productivity becomes even more substantial. Nontradable productivity and US government spending are not statistically significant, while foreign government spending is. The terms of trade variable itself is not statistically significant, which contrasts strongly with the results obtained by DeGregorio and Wolf (1994). This suggests that terms of trade effects may have their greatest impact on exchange rates at high frequencies.

The regression incorporating the income per capita variable is very successful in some respects. The estimated coefficient is highly significant. Yet, its inclusion causes both the nontradables and the US government spending coefficients to become economically and statistically significant in the wrong direction; this result suggests the presence of multicollinearity.

Finally, inclusion of the price of oil yields in some respects unsatisfactory results. While the rate of reversion is still statistically significant, the other productivity coefficients are not statistically significant. The price of oil itself is significant at the $5 \% \mathrm{MSL}$, suggesting that the cointegrating vector should include this variable.

One alternative interpretation of these findings is that they are due to a statistical artifact. Total factor productivity is measured as a residual of output and factor inputs. It is possible that exchange rate appreciation reduces the prices of imported goods which serve as intermediate inputs in the production process. This may in turn cause measured TFP to look larger, when in fact the calculated change is entirely due to mis-measurement. The correlation 
is once again negative, but for a different reason than that posited in the theoretical section of the paper. ${ }^{13}$

We attempt to address this concern by considering an empirical implication of this reverse causation. If exchange rate movements induce the mis-measurement of TFP, one might expect that the real exchange rate, or the cointegrating vector, should Granger cause TFP. In fact, one does find that this is the case in the data. However, the level of significance is about half of that for TFP causing the real exchange rate. Moreover, the economic magnitude for this reverse causation effect is much smaller -- roughly a fifth of the original channel. Hence, the bulk of the correlation seems to be attributable to productivity affecting the exchange rate.

\subsection{Panel Cointegration Results}

Since the estimated rate of reversion is always statistically significant, we can be reasonably confident that the regressions include the cointegrating vector. We calculated the Levin and Lin (1992) statistic for the composite variable implied by each of these sets of estimates. These statistics are reported at the bottom of Table 3 . They indicate that all of the series reject the unit root null. Hence, there appears to be substantial evidence for cointegration. $^{14}$

13 We thank Rich Lyons for bringing this issue to our attention.

14 Note that since the cointegration vector coefficients are estimated, the Levin and Lin critical values are not, strictly speaking, appropriate. However, the test statistics far exceed the critical values, so one may be reasonably confident about the findings. Pedroni (1995) provides appropriate test statistics, but has not yet tabulated the critical values for cointegration tests for cointegrating vectors with more than two variables. 
The specification including the preferences variable garners the greatest support on the basis of the t-statistic. However, given the difficulty in interpreting this particular cointegrating vector, our preferred model is that with the next highest t-statistic. This is the basic specification including only real exchange rates, productivity levels and government spending.

\section{Trend Exchange Rates: Productivity-Based Models vs. PPP}

One reason to estimate the relationships in levels is because one wishes to make statements about the current level of the real exchange rate relative to some trend level. In principle, when one has estimated the cointegrating relationship, one can undertake this exercise. In Figures 5-17, the actual log real exchange rate (with the prefix LRX), and the rate predicted by the model in Column 5 of Table 4 (with the suffix HAT) are depicted. ${ }^{15}$

Since the conception and estimation of equilibrium real exchange rates is a contentious issue, it is useful to compare our estimates with more familiar measures. One common measure of equilibrium real exchange rates provided by purchasing power parity. BoucherBreuer (1994) surveys this vast literature, as does Ronald MacDonald (1995). To provide some perspective on the significance of the productivity factor, we present a PPP-based measure of the real exchange rate. A strict interpretation of the PPP hypothesis would require that the long run real exchange rate is a constant. Instead of adopting a this restrictive interpretation, we allow the cointegrating vector coefficients to deviate from unity (although

15 The error correction specifications do not provide the constant in the cointegrating vector. We estimate this value by taking the average of the deviation from trend over the period. 
symmetry is imposed). This approach can be justified by appeal to measurement error and/or non-identical CPI baskets (see Cheung and Lai, 1993b).

We regress the log nominal exchange rate on log relative CPIs, applying an EngleGranger regression to the $1960-94$ data, exchange rate by exchange rate.

$$
s_{t}=\mu_{0}+\mu\left(p_{t}^{U S}-p_{t}^{*}\right)+u_{t}
$$

This equation is used to predict the nominal exchange rate, from which the log relative prices are subtracted in order to generate a PPP-predicted real exchange rate. These PPP exchange rates are also included in Figures 5-17.

Clearly the productivity based measure is more variable than the PPP-based equilibrium rate. In only one case (\$/Norwegian Krone) does the variability of the two rates come close to the same level. Another characteristic of the estimated equilibrium rates is that they consistently miss the late-1970s depreciation of the dollar as well as the mid-1980s appreciation.

The 1991 deviations from trend are reported in Table 4. A positive entry denotes a $\$$ overvaluation. The two criteria do not predict substantially different 1991 trend exchange rates for the $\$$ bilateral rates for the UK, France, Germany, Italy, Denmark, Sweden, Finland and Australia. The \$/Belgian France, the Guilder and Japanese Yen are the cases in which the PPP criterion implies greater Dollar undervaluation than the productivity-based model.

We focus on the $\$ /$ Yen case which has been closely scrutinized in the past. In line with other studies using a PPP criterion, our PPP-based measure implies a substantial undervaluation of the Dollar relative to the Yen in 1991 (49\% in log terms). In contrast, the 
productivity based model indicates a much smaller overvaluation of $15.5 \%$. If the comparison were to be extended to 1994 , it is very likely that a similar pattern would persist. ${ }^{16}$

\section{Conclusions}

Our main conclusions are as follows:

1. It is extremely difficult to find a cointegrating relationship between the real exchange rate, sectoral productivity levels, and government spending in 22 years of data, for an individual exchange rate.

2. According to the Levin-Lin test, there is more evidence in favor of cointegration when analyzing panel data. The cointegrating vector definitely contains the real exchange rate and relative sectoral productivity levels, and government spending ratios. With less certainty, it includes the real price of oil. The cointegrating vector may also include the terms-of-trade, income per capita, although the evidence here is more ambiguous.

3. Estimates of rates of reversion and of the cointegrating vector are more reliably estimated when using panel data. The half-life of a deviation from trend is on the order of four to five years. A one percent innovation in tradable sector productivity induces between a .2 to .5 appreciation in the real exchange rate.

${ }^{16}$ Chinn (1996) estimates a single-equation error correction model that implies no misalignment of the Dollar in 1991 and an $16 \%$ undervaluation in mid-1995. However, those estimates do not incorporate estimates for the effect of nontradables productivity growth. 
4. The productivity-based model usually implies smaller undervaluations of the Dollar than a PPP-based model. The most pronounced case of this phenomenon is the $\$ / Y$ case.

The extensions are fairly obvious. The small sample characteristics of the panel cointegration test need to be investigated. Appropriate tests need to be applied to investigate the validity of restrictions imposed (the same slope coefficients across currencies). Relatedly, the sensitivity of likelihood ratio test to various types of mis-specification needs to be investigated. In a related vein, alternative cointegration tests which rely upon less restrictive assumptions, such as those developed by Pedroni (1995) could be applied to the data. 


\section{References}

Asea, Patrick and W. Max Corden, 1994, "The Balassa-Samuelson Model: An Overview," Review of International Economics 2: 191-200.

Balassa, Bela, 1964, "The Purchasing Power Parity Doctrine: A Reappraisal, " Journal of Political Economy 72: 584-596.

Banerjee, Anindya, Juan Dolado, John W. Galbraith and David Hendry, 1993, Cointegration, Error-Correction, and the Econometric Analysis of Non-Stationary Data (Oxford Univ. Press: Oxford).

Breuer, Janice Boucher, 1994, "An Assessment of the Evidence on Purchasing Power Parity," in John Williamson (ed.), Estimating Equilibrium Exchange Rates (Washington, DC: Institute for International Economics): 245-277.

Canzoneri, Matthew, Robert Cumby and Behzad Diba, 1996, "Relative Labor Productivity and the Real Exchange Rate in the Long Run: Evidence for a Panel of OECD Countries," Mimeo (Georgetown University, March).

Cheung, Yin-Wong and Kon. S. Lai, 1993a, "Finite-Sample Sizes of Johansen's Likelihood Ratio Tests for Cointegration," Oxford Bulletin of Economics and Statistics 55(3): 313-328

Cheung, Yin-Wong and Kon. S. Lai, 1993b, "Long-Run Purchasing Power Parity during the Recent Float," Joumal of International Economics 34: 181-92.

Chinn, Menzie, 1995, "Paper Pushers or Paper Money? Empirical Assessment of Fiscal and Monetary Models of Real Exchange Rates," forthcoming, Journal of Policy Modeling.

Chinn, Menzie, 1996, "Whither the Yen? Implications of an Intertemporal Model of the Yen/Dollar Rate," Mimeo.

Chinn, Menzie and Richard Meese, 1995, "Banking on Currency Forecasts: How Predictable Is Change in Money?" Journal of International Economics 38(1-2) (February): 161-179.

DeGregorio, Jose and Holger Wolf, 1994, "Terms of Trade, Productivity, and the Real Exchange Rate," NBER Working Paper \#4807 (July).

DeGregorio, Jose, Alberto Giovannini, and Holger Wolf, 1994, "International Evidence on Tradables and Nontradables Inflation," European Economic Review 38: 1225-1244.

Edison, Hali, 1987, "Purchasing Power Parity in the Long Run: A Test of the Dollar/Pound Exchange Rate (1890-78)", Journal of Money, Credit and Banking 19(3): 376-87. 
Frankel, Jeffrey and Andrew Rose, 1996, "A Panel Project on Purchasing Power Parity: Mean Reversion within and between Countries," Journal of International Economics 40(1/2): 209-224.

Froot, Kenneth and Kenneth Rogoff, 1991, "The EMS, the EMU and the Transition to a Common Currency," NBER Macroeconomics Annual 1991 (MIT Press): 269-317.

Hsieh, David, 1982, "The Determination of the Real Exchange Rate: The Productivity Approach," Journal of International Economics 12 (2) (May), 355-362.

Isard, Peter and Steven Symansky, 1995, "Long Run Movements in Real Exchange Rates," Mimeo. (International Monetary Fund).

Johansen, Søren, 1988, "Statistical Analysis of Cointegrating Vectors," Journal of Economic Dynamics and Control 12: 231-54.

Johansen, Søren, and Katerina Juselius, 1990, "Maximum Likelihood Estimation and Inference on Cointegration - With Applications to the Demand for Money," Oxford Bulletin of Economics and Statistics 52: 169-210.

Levin, Andrew and Chien-Fu Lin, 1992, "Unit Root Tests in Panel Data: Asymptotic and Finite Sample Properties," Mimeo (UCSD: La Jolla, April).

MacDonald, Ronald, 1995, "Long Run Exchange Rate Modeling," IMF Staff Papers 42(3) (September): 437-489.

Marston, Richard, 1990, "Systematic Movements in Real Exchange Rates in the G-5: Evidence on the Integration of Internal and External Markets," Journal of Banking and Finance 14(5) (November): 1023-1044.

Micossi, Stefano, and Gian Maria Milesi-Ferretti, 1994, Real Exchange Rates and the Prices of Nontradable Goods," IMF Working Paper \#94/19 (February).

O'Connell, Paul, 1996, "The Overvaluation of Purchasing Power Parity," Mimeo (Harvard University, April).

Osterwald-Lenum, M., 1992, "A Note with Quantiles of the Asymptotic Distribution of the Maximum Likelihood Cointegration Rank Test Statistics, " Oxford Bulletin of Economics and Statistics 54: 461-472.

Pedroni, Peter, 1995, "Panel Cointegration: Asymptotic and Finite Sample Properties of Pooled Time Series Tests with an Application to the PPP Hypothesis," Working Paper 95013 (Department of Economics, Indiana University). 
Phillips, Peter C.B. and Mico Loretan, 1991, "Estimating Long-run Equilibria," Review of Economic Studies 58: 407-436.

Rogoff, Kenneth, 1992, "Traded Goods Consumption Smoothing and the Random Walk Behavior of the Real Exchange Rate," Bank of Japan Monetary and Economic Studies 10(2): 1-29. Also, NBER Working Paper \#4119 (July 1992).

Roldos, Jorge E., 1990, "The Terms of Trade and the Real Exchange Rate," Mimeo (September).

Samuelson, Paul, 1964, "Theoretical Notes on Trade Problems," Review of Economics and Statistics 46: 145-154.

Strauss, Jack, 1995, "Real Exchange Rates, PPP and the Relative Price of Nontraded Goods," Southern Economic Journal 61(4) (April): 991-1005.

Wei, Shang-Jin and David Parsley, 1995, "Purchasing Power DisParity during the Floating Rate Period: Exchange Rate Volatility, Trade Barriers and Other Culprits," NBER Working Paper \#5032 (February).

Wolff, Christian C.P, 1987, "Time-Varying Parameters and the Out-of-Sample Forecasting Performance of Structural Exchange Rate Models," Journal of Business and Economic Statistics 5(1): 87-97. 
Table 1

Previous Estimates of Productivity Coefficients

\begin{tabular}{|c|c|c|c|}
\hline & $\begin{array}{l}\text { Hsieh } \\
(1982)\end{array}$ & $\begin{array}{l}\text { Marston } \\
(1990)\end{array}$ & $\begin{array}{l}\text { Micossi \& } \\
\text { Miles } i- \\
\text { Ferretti } \\
(1994)\end{array}$ \\
\hline$B_{1}$ & $\begin{array}{l}-0.36 \text { to } \\
-0.52\end{array}$ & $\begin{array}{l}-0.71 \text { to } \\
-1.24\end{array}$ & $\begin{array}{l}-0.10 \text { to } \\
-0.76\end{array}$ \\
\hline$\beta_{2}$ & 0.54 & $\begin{array}{l}0.71 \text { to } \\
1.24\end{array}$ & $\begin{array}{l}-0.29 \text { to } \\
1.10\end{array}$ \\
\hline $\begin{array}{l}\text { Exchange } \\
\text { rate var. }\end{array}$ & $\begin{array}{l}\text { multi- } \\
\text { lateral }\end{array}$ & bi latera 1 & $\begin{array}{l}\text { mu1ti- } \\
\text { latera } 1\end{array}$ \\
\hline Currencies & $¥$, DM & $\begin{array}{l}\$ / 7, \$ / F F r \\
\$ / D M, \$ / 千 \\
\text { Ffr/DM }\end{array}$ & $\begin{array}{l}\text { BFr, DM } \\
\text { FFr, DKr } \\
\text { LIt, } F L, f\end{array}$ \\
\hline $\begin{array}{l}\text { Productivity } \\
\text { variable }\end{array}$ & $\begin{array}{l}\text { labor } \\
\text { in mfg. } \\
\text { svcs. }\end{array}$ & $\begin{array}{l}\text { labor } \\
\text { in } \mathrm{mfg} . \\
\text { svcs. }\end{array}$ & $\begin{array}{l}\text { labor in } \\
\text { mfg., svcs }\end{array}$ \\
\hline Samp le & $1954-76$ & $1973-86$ & $1960-90$ \\
\hline Frequency & annua 1 & annua 1 & annua 1 \\
\hline Spec if ication & diffs. & diffs. & diffs. \\
\hline $\begin{array}{l}\text { Estimation } \\
\text { technique }\end{array}$ & IV/AR & OLS & OLS \\
\hline Comments & $\begin{array}{l}\text { Equation } \\
\text { includes } \\
\text { relative } \\
\text { unit labor } \\
\text { costs }\end{array}$ & & $\begin{array}{l}\text { Equation } \\
\text { includes } \\
\text { relative } \\
\text { unit labor } \\
\text { costs }\end{array}$ \\
\hline
\end{tabular}


Table 1 (continued)

Previous Estimates of Productivity Coefficients

\begin{tabular}{|c|c|c|c|}
\hline & $\begin{array}{l}\text { DeGregor io } \\
\& \text { Wo If } \\
(1994)\end{array}$ & $\begin{array}{l}\text { Rogoff } \\
(1992)\end{array}$ & $\begin{array}{l}\text { Chinn } \\
(1995)\end{array}$ \\
\hline$B_{1}$ & $\begin{array}{l}-0.36 \text { to } \\
-0.52\end{array}$ & $\begin{array}{l}-0.6 \text { to } \\
-0.7\end{array}$ & $\begin{array}{l}2.21 \text { to } \\
-0.82\end{array}$ \\
\hline$B_{2}$ & 0.54 & $\begin{array}{l}0.6 \text { to } \\
0.7\end{array}$ & $\begin{array}{l}-2.21 \text { to } \\
0.82\end{array}$ \\
\hline $\begin{array}{l}\text { Exchange } \\
\text { rate var. }\end{array}$ & $\begin{array}{l}\text { multi- } \\
\text { latera }\end{array}$ & bilateral & bilateral \\
\hline Currencies & OECD 14 & $\$ / ¥$ & $\begin{array}{l}\$ / C \$, \$ / D M \\
\$ / \#, \$ / £\end{array}$ \\
\hline $\begin{array}{l}\text { Productivity } \\
\text { variable }\end{array}$ & $\begin{array}{l}\text { TFP in mfg. } \\
\text { \& services }\end{array}$ & $\begin{array}{l}\text { labor } \\
\text { in mfg. }\end{array}$ & $\begin{array}{l}\text { labor in } \\
\text { mfg. }\end{array}$ \\
\hline Sample & $1970-85$ & $81.1-90.3$ & $1974.1-93.3$ \\
\hline Frequency & annua 1 & quarterly & quarterly \\
\hline Specification & diffs. & diffs. & levels \\
\hline $\begin{array}{l}\text { Estimation } \\
\text { technique }\end{array}$ & SUR & OLS & $\begin{array}{l}\text { dynamic } \\
\text { OLS }\end{array}$ \\
\hline Comments & $\begin{array}{l}\text { Equation } \\
\text { includes } \\
\text { terms of } \\
\text { trade, gov. } \\
\text { exp., income }\end{array}$ & $\begin{array}{l}\text { Equation } \\
\text { includes } \\
\text { gov. exp. }\end{array}$ & $\begin{array}{l}\text { Equation } \\
\text { includes } \\
\text { gov. exp. }\end{array}$ \\
\hline
\end{tabular}


Table 2

Single-Equation Estimates of Four Variable Model 1970-91

\begin{tabular}{|c|c|c|c|c|}
\hline $\begin{array}{l}\text { Exch. } \\
\text { Rate }\end{array}$ & NLS ECM & $\begin{array}{l}\text { NLS ECM } \\
\text { w/trend }\end{array}$ & \multicolumn{2}{|c|}{ Phillips-Loretan } \\
\hline $\begin{array}{l}\text { GBR } \\
\text { FRA } \\
\text { DEU } \\
\text { ITA } \\
\text { CAN } \\
\text { JPN } \\
\text { BEL } \\
\text { DNK } \\
\text { NLD } \\
\text { NOR } \\
\text { SWE } \\
\text { FIN } \\
\text { AUS }\end{array}$ & $\begin{array}{l}-0.45 * \star * \\
-0.51 * * * \\
-0.37 \\
-0.15 \\
-0.04 \\
-0.14 \\
-0.24 \\
-0.36 * * \\
-0.35 * \star \\
-0.16 \\
-0.42 * \star * \\
-0.40 * \star * \\
-0.20\end{array}$ & $\begin{array}{l}-0.48 * * * \\
-0.49 * * \\
-0.40 * * \\
-0.64 * \star \\
-0.07 \\
-0.67 * * * \\
-0.46 * * \\
-0.42 * * * \\
-0.42 * \star \\
-0.23 * \\
-0.37 * * \\
-0.39 * * * \\
-0.17\end{array}$ & $\begin{array}{l}-0.66 * \star \\
-0.60 * * \\
-0.48 * * \\
-0.25 \\
-0.28 * \\
-0.38 \\
-0.34 \\
-0.60 * * * \\
-0.72 * * * \\
-0.39 * \\
-0.80 * * \\
-0.61 * * \\
-0.12\end{array}$ & 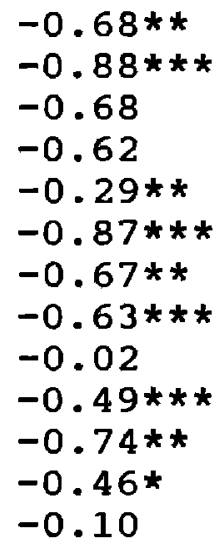 \\
\hline Panel & ficient & Tradable & letivity, & $<0$ \\
\hline $\begin{array}{l}\text { Exch. } \\
\text { Rate }\end{array}$ & NLS ECM & $\begin{array}{l}\text { NLS ECM } \\
w / \text { trend }\end{array}$ & NLS ECM & $\begin{array}{l}\text {-Loretan } \\
\text { w/trend }\end{array}$ \\
\hline $\begin{array}{l}\text { GBR } \\
\text { FRA } \\
\text { DEU } \\
\text { ITA } \\
\text { CAN } \\
\text { JPN } \\
\text { BEL } \\
\text { DNK } \\
\text { NLD } \\
\text { NOR } \\
\text { SWE } \\
\text { FIN } \\
\text { AUS }\end{array}$ & $\begin{array}{l}1.80 * \\
2.55 * \\
3.68 * \star \\
0.09 \\
-1.56 \\
-2.97 \\
0.46 \\
2.42 \\
0.19 \\
5.89 \\
3.43 * \\
5.00 * \star \star \\
5.73\end{array}$ & $\begin{array}{l}2.30 \\
2.51 \\
3.35 \star \\
3.19 \\
-2.09 \\
3.56 \\
4.00 * \star \\
3.02 \star \\
1.10 \\
2.81 \\
2.87 \\
4.98 * \star \star \\
5.21\end{array}$ & $\begin{array}{l}3.38 * \\
1.78 \\
3.18 \\
1.43 \\
-0.55 \\
-1.50 \\
-1.39 \\
4.11 * \star \star \\
0.73 \\
3.05 \\
3.48 * \star \\
3.32 \\
10.23 *\end{array}$ & $\begin{array}{l}3.47 \star \\
0.94 \\
3.48 \\
4.15 \\
-0.34 \\
2.27 \\
2.38 \star \\
4.09 \star \star \star \\
-0.59 \\
1.82 \\
2.74 \\
2.93 \\
28.22 \approx\end{array}$ \\
\hline
\end{tabular}

Notes: NLS ECM is nonlinear least squares error correction model (no lags of first differences). Phillips-Loretan NLS ECM including 1 lead of the independent variables. "w/trend" indicates a time trend is included. $*(* *)[* * *]$ indicates significance at the $10 \%(5 \%)[1 \%]$ level. a Includes one lead of $\mathrm{g}_{\mathrm{AOS}}$, only. 
Table 3

SUR Estimation Results:

Determinants of Rea 1 Exchange Rate

$\begin{aligned} & \text { Predicted (1) } \\ & \text { sign }\end{aligned}$
Param.

\begin{tabular}{|c|c|c|c|c|c|c|}
\hline ECT & $(-)$ & $\begin{array}{l}-0.169 \star \star \star \\
(0.028)\end{array}$ & $\begin{array}{l}-0.146^{\star \star \star} \\
(0.028)\end{array}$ & $\begin{array}{l}-0.185^{* * *} \\
(0.028)\end{array}$ & $\begin{array}{l}-0.228^{* \star \star *} \\
(0.022)\end{array}$ & $\begin{array}{l}-0.166 * * \star \\
(0.028)\end{array}$ \\
\hline$\hat{a}^{\top}$ & $(-)$ & $\begin{array}{l}-0.390^{\star \star} \\
(0.155)\end{array}$ & $\begin{array}{l}-0.502 \star \star \\
(0.182)\end{array}$ & $\begin{array}{l}-0.894 \star \star \star \\
(0.164)\end{array}$ & $\begin{array}{l}-0.224^{* \star} \\
(0.094)\end{array}$ & $\begin{array}{l}-0.180 \\
(0.160)\end{array}$ \\
\hline$\hat{a}^{M}$ & $(+)$ & $\begin{array}{l}0.144 \\
(0.126)\end{array}$ & $\begin{array}{l}-0.013 \\
(0.145)\end{array}$ & $\begin{array}{l}0.233 \\
(0.185)\end{array}$ & $\begin{array}{l}-0.562^{\star \star \star} \\
(0.145)\end{array}$ & $\begin{array}{l}0.074 \\
(0.177)\end{array}$ \\
\hline$g^{\text {US }}$ & $(-)$ & $\begin{array}{l}-10.05^{\star \star \star} \\
(2.978)\end{array}$ & $\begin{array}{l}0.079 \\
(1.190)\end{array}$ & $\begin{array}{l}-4.871 \\
(3.041)\end{array}$ & $\begin{array}{l}13.358^{\star \star \star} \\
(3.166)\end{array}$ & $\begin{array}{l}-8.016^{\star} \\
(4.508)\end{array}$ \\
\hline * & $(+)$ & $\begin{array}{l}-3.169 \star \star \\
(1.222)\end{array}$ & $\begin{array}{l}-0.079 \\
(1.190)\end{array}$ & $\begin{array}{l}-5.691^{\star \star \star} \\
(1.349)\end{array}$ & $\begin{array}{l}0.328 \\
(0.655)\end{array}$ & $\begin{array}{l}-3.359^{* *} \\
(1.302)\end{array}$ \\
\hline
\end{tabular}

tot $(-)$

0.031

$(0.101)$

$\hat{y}-\hat{n} \quad(-)$

$-1.474 * * *$

$(0.133)$

$p^{\text {oll }}(?)$

-0.201 **

$(0.075)$

$\begin{array}{llllll}\overline{\mathrm{R}}^{2} & .35-.80 & .40-.80 & .27-.71 & .24-.71 & .40-.73 \\ \mathrm{~N} & 22 & 22 & 22 & 22 & 22 \\ \mathrm{t} & -6.555^{\star \star \star *} & -5.926 \star \star \star & -6.184 \star \star \star & -7.393^{\star \star *} & -4.755^{\star \star \star}\end{array}$

Notes: OLS standard errors in parentheses. ECT is the coefficient on the cointegrating vector; the cointegrating vectors are normalized on the real exchange rate. Ranges for adjusted $-R^{2 /} s$ are for the 13 equations in the SUR results. " $t$ " is the $t$-statistic on a regression of the first difference of the error correction term on the lagged error correction term and currency specific dummies; critical values from Levin and Lin (1992). *(**)[***] indicates significance at the $10 \%(5 \%)[1 \%]$ marginal significance leve 1 . 
Tab le 4

Estimates of Deviation from Trend

\begin{tabular}{lcrl}
\hline \hline $\begin{array}{l}\text { Exch. } \\
\text { Rate }\end{array}$ & Year & \multicolumn{1}{l}{$\begin{array}{l}\text { Model } \\
\text { Deviation }\end{array}$} & $\begin{array}{l}\text { PPP implied } \\
\text { Deviation }\end{array}$ \\
\hline GBR & 1991 & 0.066486 & 0.120598 \\
FRA & 1991 & 0.010672 & 0.071856 \\
DEU & 1991 & -0.073526 & 0.014299 \\
ITA & 1990 & 0.164151 & 0.199658 \\
CAN & 1991 & 0.012299 & 0.125170 \\
JPN & 1991 & 0.155013 & 0.488702 \\
BEL & 1991 & -0.088758 & 0.150956 \\
DNK & 1990 & 0.127467 & 0.120946 \\
NLD & 1990 & 0.031212 & 0.209298 \\
NOR & 1991 & 0.076252 & 0.002576 \\
SWE & 1991 & 0.115199 & 0.125528 \\
FIN & 1991 & 0.248024 & 0.168149 \\
AUS & 1991 & -0.025220 & 0.037712 \\
\hline
\end{tabular}

Notes: Year is the year the comparison is made. Actual real exchange rate minus predicted, in log-levels. Exchange rates expressed in US $\$ /$ foreign currency unit. 


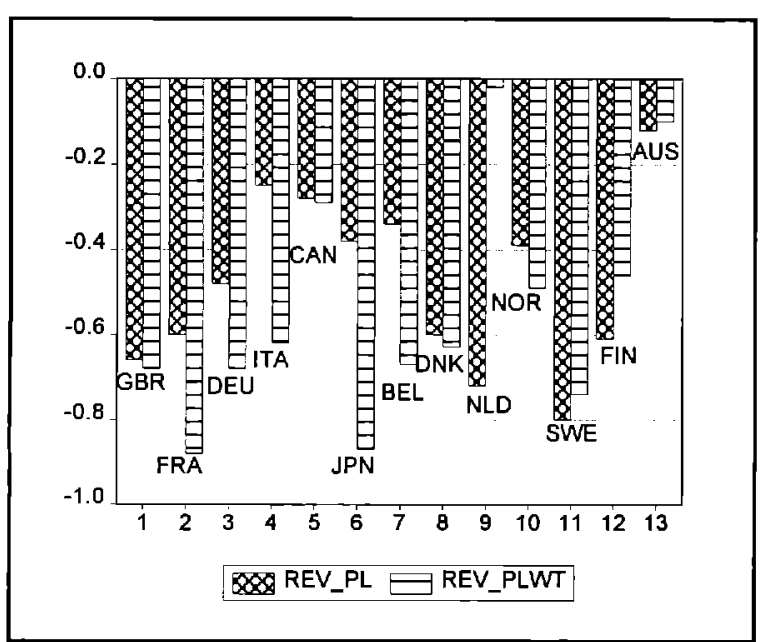

Figure 1: ECM and PL Estimates of the Rate of Reversion

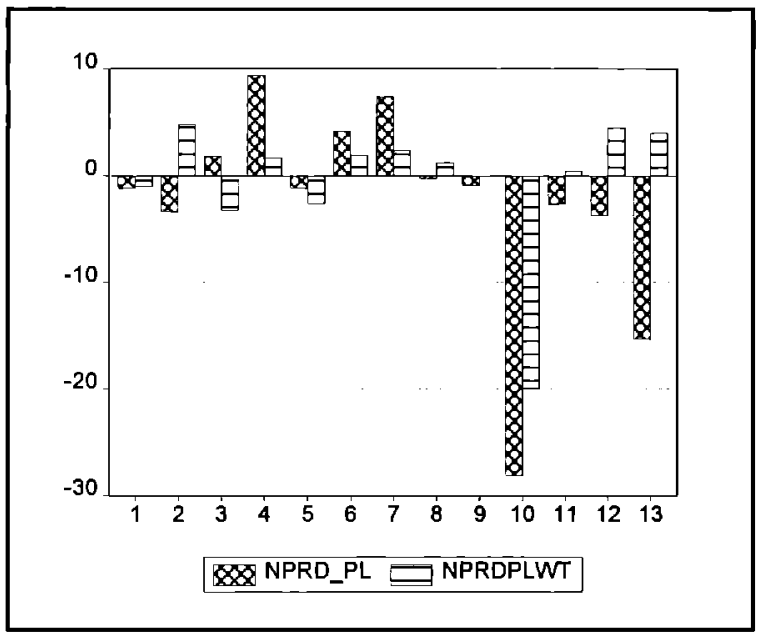

Figure 3: ECM and PL Estimates of the Nontradables Sector Productivity coefficient

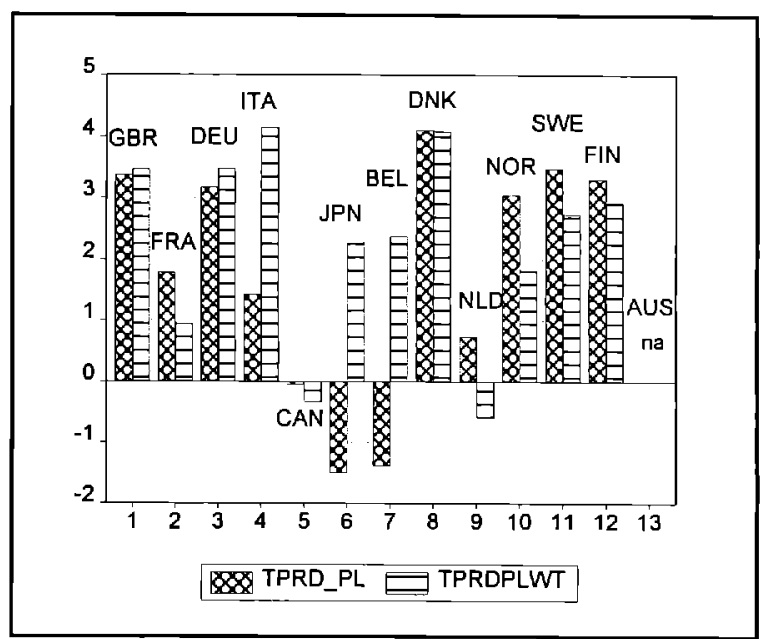

Figure 2: ECM and PL Estimates of the Tradables Sector Productivity coefficient

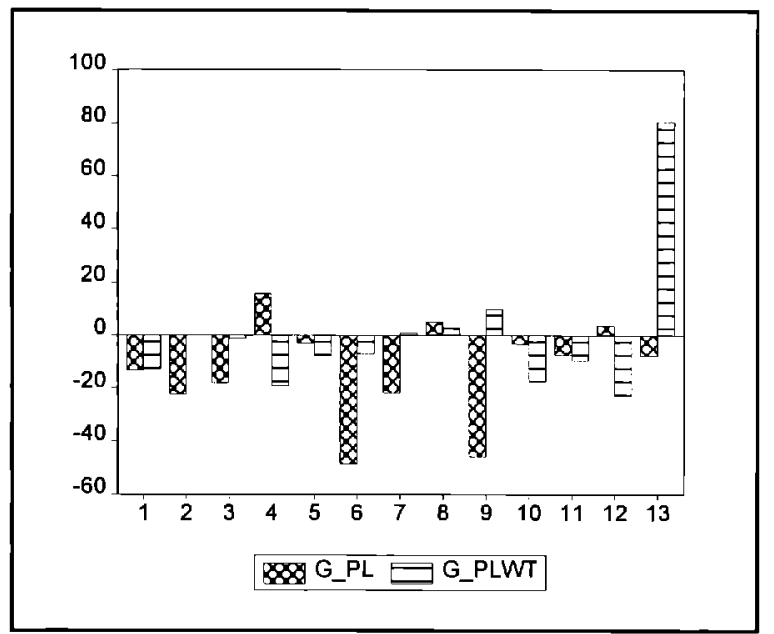

Figure 4: ECM and PL Estimates of the Foreign Government Spending Coefficient 


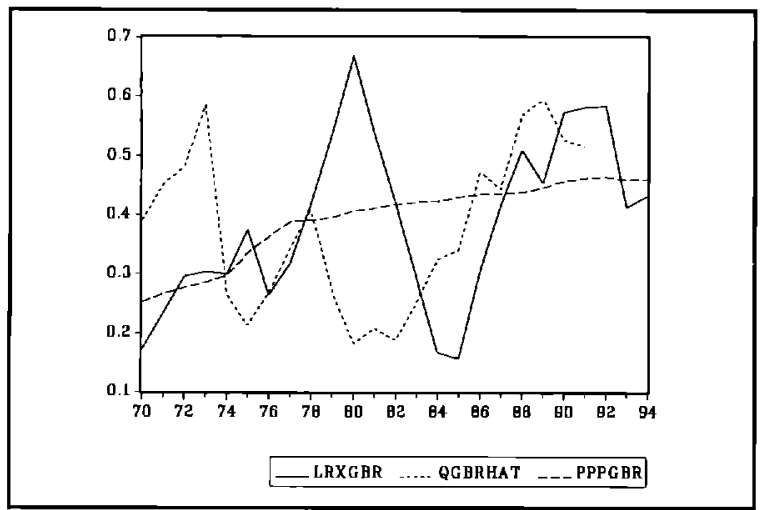

Figure 5: United Kingdom

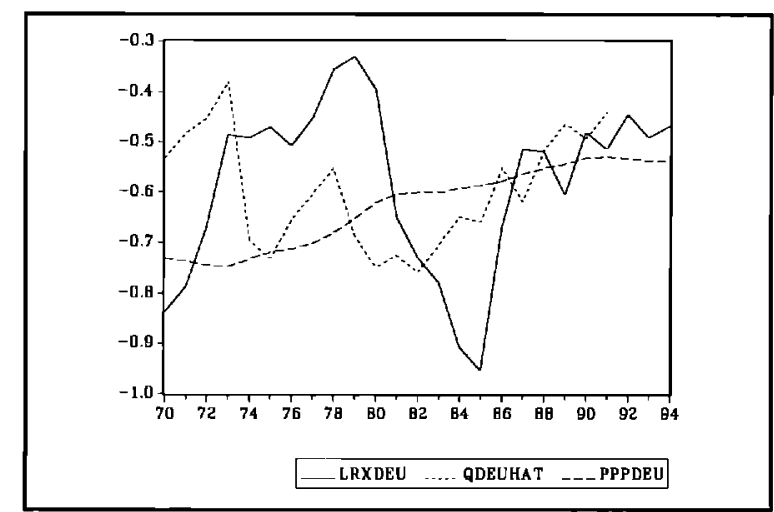

Figure 7: West Germany

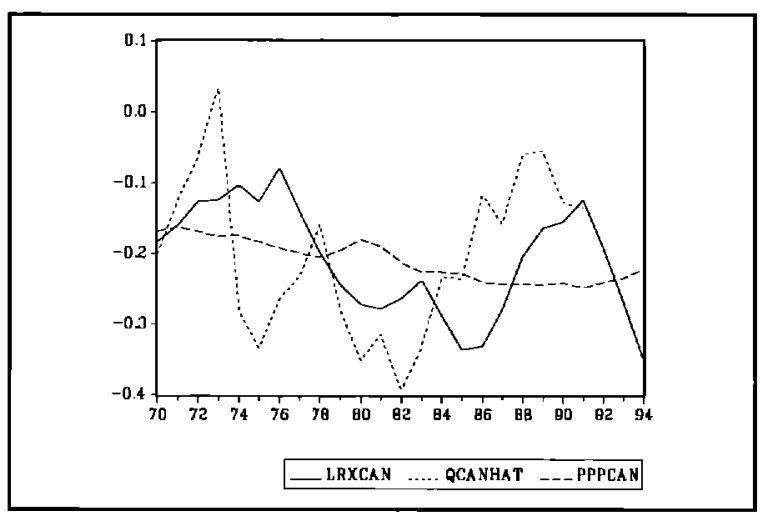

Figure 9: Canada

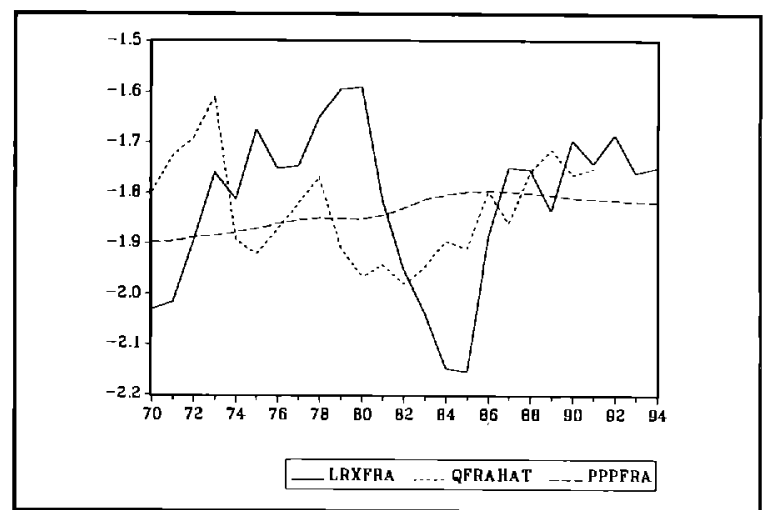

Figure 6: France

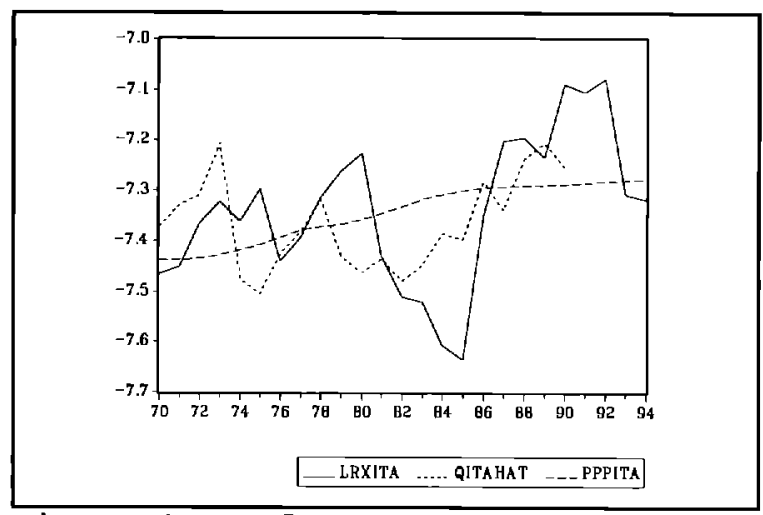

Figure 8: Italy

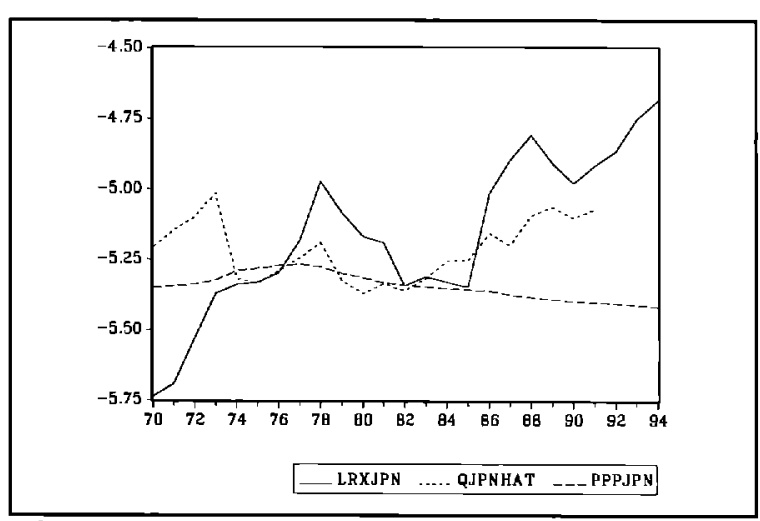

Figure 10: Japan 


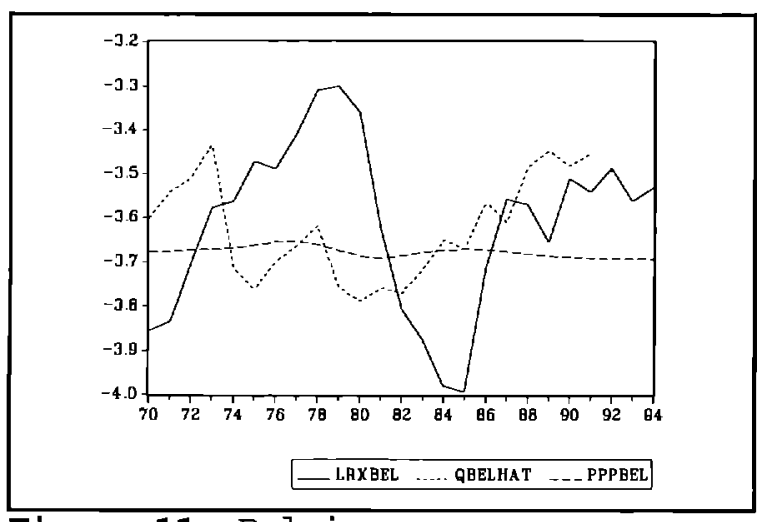

Figure 11: Belgium

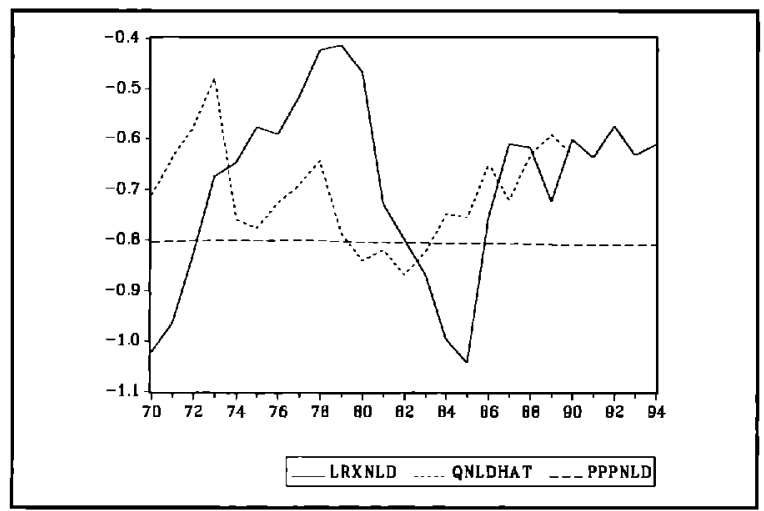

Figure 13: Netherlands

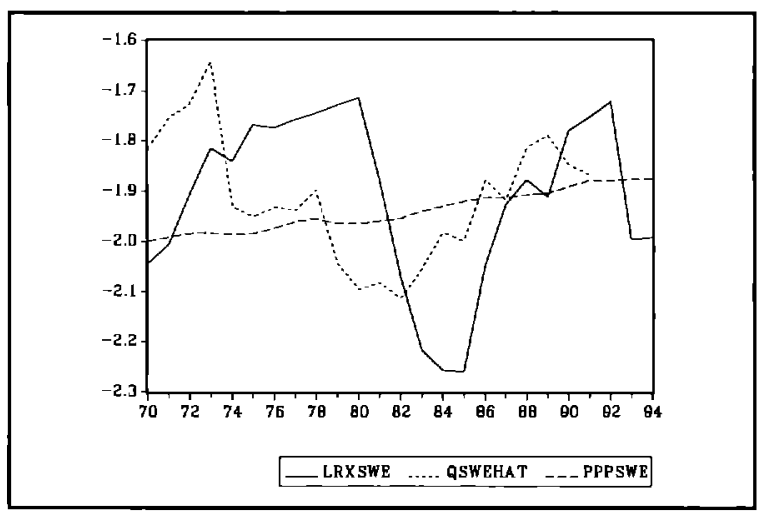

Figure 15: Sweden

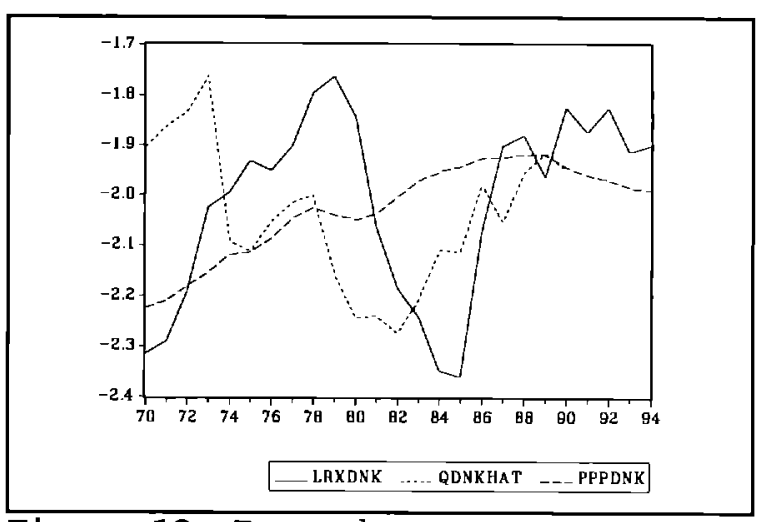

Figure 12: Denmark

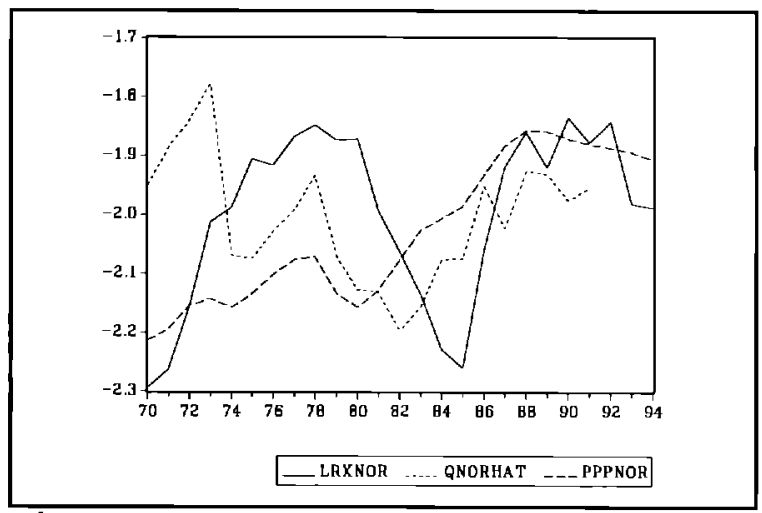

Figure 14: Norway

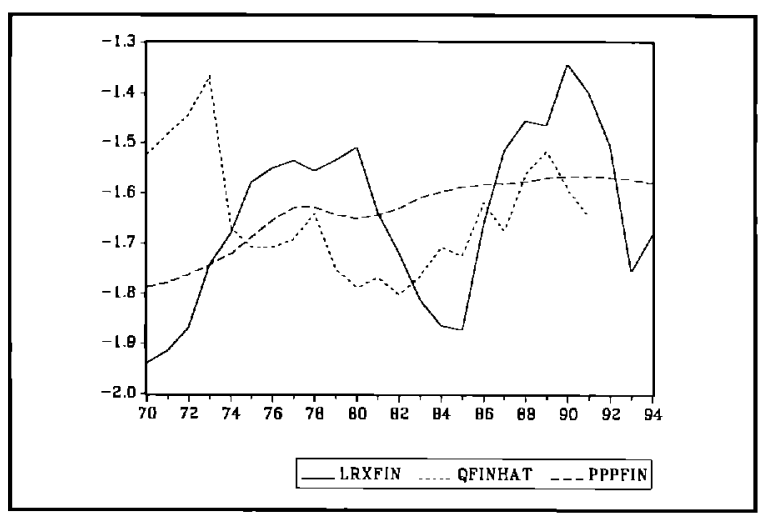

Figure 16: Finland 


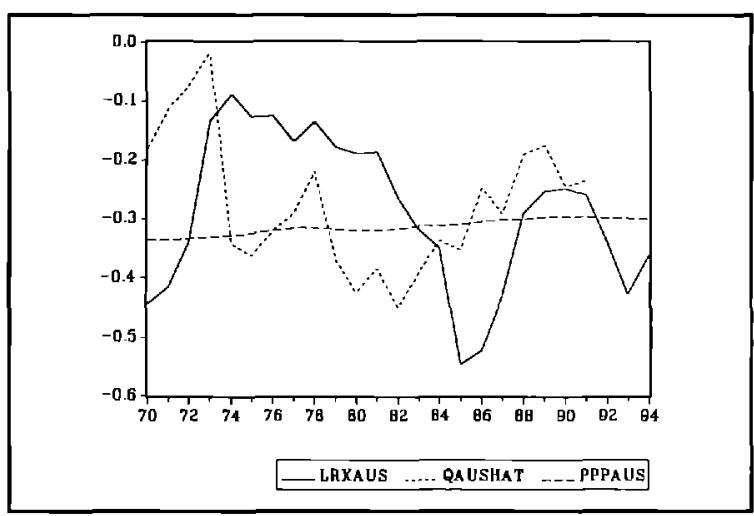

Figure 17: Australia. 